\title{
Efforts to increase nutritional status among Cytomegalovirus (CMV) infected children
}

\author{
Iroma Maulida, Ratih Sakti Prastiwi, Umriaty
}

Midwifery Diploma Program, Polytechnic Harapan Bersama, Indonesia

\begin{tabular}{|c|c|}
\hline Article Info & ABSTRACT \\
\hline $\begin{array}{l}\text { Article history: } \\
\text { Received Nov 20, } 2019 \\
\text { Revised Apr 13, } 2020 \\
\text { Accepted Apr 24, } 2020\end{array}$ & $\begin{array}{l}\text { Malnutrition has an interrelated relationship with infectious diseases, } \\
\text { where infection can occur malnutrition and can cause malnutrition } \\
\text { in children. Children who infected with CMV need an increase in nutritional } \\
\text { status, but with malnutrition, the recovery process and the body's immune } \\
\text { enhancement cannot be optimal. This study aimed to identify the efforts } \\
\text { to improve the nutritional status of children infected with CMV in Tegal, }\end{array}$ \\
\hline $\begin{array}{l}\text { Keywords: } \\
\text { Children } \\
\text { Cytomegalovirus } \\
\text { Infected } \\
\text { Nutritional }\end{array}$ & $\begin{array}{l}\text { Central Java, Indonesia. This study was a qualitative study with } \\
\text { phenomenological approach. The informants were parents or caregivers } \\
\text { of the children infected with CMV. Data obtained through interviews and } \\
\text { observations, which then analyzed through the stages of data } \\
\text { reduction-presentation-drawing conclusions. Data were analyzed using } \\
\text { triangulation methods. The results showed that the nutritional status } \\
\text { of children after recovery of CMV infection had increased. That was because } \\
\text { the informant always ensures nutrients needed even given using a soft texture } \\
\text { and gradually increase to rough. The tendency of informants to provide } \\
\text { the same food has the risk of increasing the deficiency of micronutrients } \\
\text { in children. Therefore we need an effort to improve the provision of food } \\
\text { variations in children. }\end{array}$ \\
\hline
\end{tabular}

This is an open access article under the $\underline{C C B Y-S A}$ license.

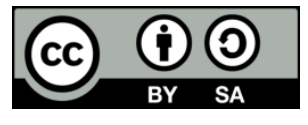

\section{Corresponding Author:}

Iroma Maulida,

Midwifery Diploma Program,

Polytechnic Harapan Bersama,

9th, Mataram Street, Margadana District, Tegal City, Central Java, Indonesia.

Email: iroma.maulida@yahoo.co.id

\section{INTRODUCTION}

Cytomegalovirus (CMV) is one of the infectious diseases found in children less than five years. Most infections occur during pregnancy and are only detected when the child is born or less than one year old. This infection is quite difficult to treat because of the high morbimortality in patients [1]. CMV is a disease that shows quite a lot of clinical manifestations, one of which is gastrointestinal disorders. Infected children show signs or symptoms such as bloody diarrhea, also necrotising enterocolitis (NEC) with perforation and intestinal stricture $[2,3]$. In the previous study, the majority of children infected with CMV in Tegal showed prolonged diarrhea [4]. This condition caused sufferers to feel bothering and inconvenient. Prolonged diarrhea also increases the risk of dehydration, weight loss, increased serum creatinine, and fluctuating levels of immunosuppressive drugs. If Children infected with CMV experience chronic diarrhea, they had a higher possibility to have malnutrition [5].

Malnutrition itself has become a public health problem, which until now has not been resolved, especially in developing countries such as Afrika and Asia [6-8]. In Indonesia, there were 23 million children under five years old, and 805,000 of them experienced acute malnutrition. Children who experience acute 
malnutrition have 11 times more significant potential to experience death than well-nourished children [9]. Malnutrition is known to increase the risk of disease transmission and various complications. If children with CMV experience diarrhea until malnutrition occur, it will affect the length of the healing process. Also, if not appropriately handled, it will increase the risk of other complications until death [10-12].

Based on the background, it is known that children who suffer from CMV must have good nutrition to speed up the healing process. However, with the presence of diarrhea, efforts to fulfill nutrition in children will be more difficult. Fulfillment of nutrition is not only done during the treatment process but also the recovery period. Malnutrition can relapse if the feeding does not meet the nutrients needed to help the healing process and recovery [13]. Therefore this study was carried out to explore information on strategies and parenting patterns undertaken by parents to improve the nutritional status of children infected with CMV from the treatment process to the recovery period.

\section{RESEARCH METHOD}

This study used a qualitative method with a phenomenological study approach. We discovered information about efforts in improving the nutritional status of children who have been diagnosed with CMV, eating patterns, and the obstacles faced by informants in fulfilling a balanced nutritional intake in children. The study conducted in the Tegal City area, Central Java, Indonesia from April-September 2018 [14, 15].

The informants in this study were taken using a purposive sampling technique with the criteria of the informants being parents who have children diagnosed with CMV, children who have experienced diarrhea, and still live in location until the study implemented. The informants were key informants and triangulation informants. The key informants in this study were a pediatrician who had handled CMV cases in infants. Key informants help directly to get informants who fit the criteria set by the researcher. The number of primary informants obtained through snowballing sampling, namely, taking the number of informants until the data obtained is saturated [16].

Data collected through in-depth interviews and observation. In-depth interviews were conducted using instruments in the form of interview guidelines and other aids such as cameras and field notes [16]. While the observation data was carried out to obtain data on the child's nutritional status by calculating body weight based on age. Nutritional status was measured using z-score weight/age and classified into malnutrition (<-3 SD), malnutrition ( -3 to $-2 \mathrm{SD})$ and good nutrition ( -2 to $+2 \mathrm{SD})$ [17].

\section{RESULTS AND DISCUSSION}

Food intake is often associated with nutritional problems in children even though the nutritional status is not always influenced by it, but it can be influenced by other factors such as an infectious disease. Most children infected with CMV are potential to experience nutritional problems. Children who had infections tend to cause a decrease in appetite, so the amount and type of nutrients which enter the body become less. Children who have infections need more nutrients because they had increased metabolism, especially children who are accompanied by fever [17, 18]. Few people rarely thought that CMV could be a significant cause of gastrointestinal infections in immunocompetent children [19]. Gastrointestinal disorders, most commonly found in children infected with CMV are diarrhea [5, 20]. The results of previous research also found that the majority of children infected with CMV had a fever and diarrhea [4]. If the condition not appropriately treated, it will be more vulnerable to the diseases entering and developing [17, 21].

"My child usually had diarrhea; it would not heal even before he was hospitalized. When he had a fever, it never reaches more than 38 Celcius, but, it was always accompanied by diarrhea, even though the medicine has been given, but it would not work "(IU.1)

"My child often had a fever, and it worries me. Then the doctor ordered the CMV test. My sister said it was very similar to the signs of CMV infection"(IU.2)

Children infected with CMV accompanied other diseases such as diarrhea have the potential to experience malnutrition. Diarrhea is a disease that can cause malnutrition in children due to mal-absorption of food intake, electrolyte imbalance, and secretory diarrhea, which causes severe dehydration and malnutrition [22], as well as children with malnutrition, can also aggravate the condition of diarrhea in children. Children who have infections would not succeed in increasing nutrition if they were not treated. Neither with the accompanying disease, even though the child had received treatment, diarrhea still did not recover. This condition caused the child's nutrition to decrease [4, 23]. The informant stated that their children looked thin when exposed to CMV. Not only that, but the parents also do not monitor the nutritional status of children regularly by weighing at the Posyandu. Poor nutritional conditions in children will further 
increase the risk of complications from infectious diseases. Children with poor nutrition will trigger changes in immune function in the body. Decreased immune function can cause loss of delayed hypersensitivity response, decreased lymphocyte response, decreased T-lymphocytes, decreased phagocytosis due to decreased complement and cytokines, and decreased immunoglobulin [24].

Based on the signs and symptoms of CMV, namely the presence of diarrhea where it is one of the causes of an increased risk of underweight and wasting, but in Table 1 shows that children with CMV and had experienced diarrhea were have good nutritional status. It could happen because the informant's child has received CMV treatment, so after that, parents could focus on recovering the child's nutritional condition. The nutritional status of children with infections would not improve if the infection has not been treated; it can repeatedly occur so that treatment needs to be completed. To restore the nutritional status is not only focus on the amount of food intake but also the composition of nutrients and their processing needs to be considered $[11,23]$.

Table 1. Nutritional status of informants

\begin{tabular}{cccccc}
\hline Informant code & Age (yo) & Age when exposed CMV (yo) & Weight (kg) & z-score (w/a) & Nutritional status \\
\hline IU.1 & 3.5 & 1 & 13 & 1.3 & Good \\
IU.2 & 2 & 7 & 9 & -2.1 & $\begin{array}{c}\text { Good/The lower limit } \\
\text { of proper nutrition }\end{array}$ \\
\hline
\end{tabular}

"We gave him food with a smooth texture and then continue to be trained to eat soft rice with vegetables. We give him in turns, in the morning we blend the rice, in the afternoon vegetable blend with rice. If it not blended, he will eat in a little bit; that is why we gave him blended food so he will not limp because he eats little." (IU.1)

The results of interviews revealed that the composition of children's food, when exposed to CMV and after infection, has no difference. Mothers provide a variety of foods that were quite varied, and the difference was the shape and preparation. Whereas in the recovery period, it is necessary to restore the metabolic condition of the child's body by fulfilling calorie, protein, and other micronutrient needs. Fulfillment of calories in children will help increase energy in vital tissues and organs, the nervous system, and the release of pituitary hormones that can help suppress recurring infections and reduce stress [23, 25]. The difference in food given before and after the infection was more to the texture of food. When children were exposed to CMV, informants provided smooth foods such as porridge by mixing various types of food. When the child was recovering, parents began to increase the texture to train the child to be able to accept rough or solid food.

"When children aged 1-2 years, children were given rice that was blended smooth mixed with broth chicken soup-sometimes given interludes such as additives foods (mention the brand) mashed or mashed fruit such as avocados, bananas, and papaya. Children were also given soy milk. Right now we gave him solid food such as fried rice, eggs and chicken, the fruit processed as juices, and the vegetables are processed as bakwan; sometimes we gave him bread as well" (IU.1)

"When he was 8-9 months, he was given a porridge mixed with vegetables and protein. Then at the age of 16 months, he was given rice mixed with milk. Right now, he loved eating rice mix with milk plus side dishes such as shrimp, eggs, or liver; sometimes rice and broth soup."

Fulfillment of macronutrients was completed by providing carbohydrates from rice, protein from meat, seafood, and eggs and fat from avocados. These ingredients can be given as snacks or given as the main menu [11]. Based on the results of interviews, when exposed, it was known that children given with a soft texture where parents or caregivers give them rice mixed with soup broth or soft rice mixed with milk. These were another effort to provide the needs of micronutrients in children. Milk is a source of energy that can be consumed by all age groups. Milk does contain not only macronutrient requirements but also many micronutrients needed, such as vitamin A, vitamin E, folic acid, vitamin B complex, vitamin C, iron, zinc, and potassium. These micronutrients were needed to improve a person's immune response. So when a child is exposed to an infection, their efforts could help rebuild the child's immune system [26]. Also, according to Olney et al., consistent nutrition fulfillment for people with malnutrition for two years in a row can increase their BMI [27].

"Nowadays, he likes fried rice. When breakfast, lunch, and dinner, We always make fried rice. Sometimes we use seasoning, so it was done quickly. If we replace other foods, he would not like it” (IU.1)

Efforts to increase nutritional status among Cytomegalovirus (CMV) infected children (Iroma Maulida) 
Nutrition fulfillment continues to be improved when the child was exposed and when in the recovery period. However, when the child gains weight, there was a change in feeding, the informants tend to provide what children want without seeing whether the nutrients needed have been met or not. One informant said that children only want to eat fried rice mixed with eggs and chicken. This practice is called permissive practice, where parents feed the child to fulfill the child's wishes. According to Blaine et al., permissive practices have a close relationship with an increase in excess calories but have low nutritional quality [28]. Providing less varied food cannot guarantee that the nutritional needs of children are met.

In this study, the informants were still less assertive in introducing varied foods so that children were reluctant to try other types of food. Therefore it is necessary to introduce food variations in children [29]. Introducing food variations can be influenced by several factors, such as the habits of parents, friends to eat, and activities [30,31]. When children eat with many people or in groups, the desire to eat will appear following what others eat. This strategy can be applied to children who have difficulty eating varied foods [32]. Also, parents need discipline and firmness in children to eat different foods. Involving children in various physical activities can also increase a child's appetite [28]. Mealtime structural practices can be another alternative to introduce and accustomed children with food variety. This practice is done by eating meals as a family so that the children could get a quality diet [33].

From the interview, it also is known that frequent consumption of fried rice results in changes in parents' behavior in using instant seasoning. Parents preference in using instant seasoning, mostly because it was convenient in terms of food preparation and feeding [34]. Another reason parents mostly using instant seasoning is because it is more appealing for their children based on taste and color on their food [34].

The content of instant seasoning itself has a high content of monosodium glutamate (MSG). MSG is made of amino acids, which is needed for nutritional fulfillment and is commonly used as a flavor enhancer. Nevertheless, some literature related to the effect of MSG on health showed that increased consumption of MSG could be associated with increased food intake and hunger, which could lead to obesity. Other literature stated that MSG also could be associated with harmful health effects such as diabetes, hepatotoxic, neurotoxic, and genotoxic effects [35]. However, according to Vorhees, consuming MSG does not affect children's neurodevelopment. Even the cumulation of MSG will not be neurotoxic. However, what needs to be considered, when we use MSG, we will not fulfill some micronutrient substances that can be obtained from herbs such as onions, garlic, chili, and other types of herbs [36].

\section{CONCLUSION}

Improvement of nutritional status in children with CMV infection can be made after the child getting treatment completely and declared cured. Nutrition improvement needs to focus on the needs of macronutrients and micronutrients. How to give can be done by giving food with a soft texture and gradually introduce children to a coarser texture. Nevertheless, parents still tend to practice feeding according to what the child wants as long as the child wants to eat, not paying attention to nutrition needs. It can lead to an increase in calories but a lack of certain nutrients. Therefore, there is a need for strategies such as increasing physical activity of children, disciplining in introducing variations in food in children, and occasionally inviting children to eat together to increase curiosity to try different types of food. That way, parents can make sure the child complies with micronutrients obtained from various types.

\section{ACKNOWLEDGEMENTS}

All authors were grateful for Polytechnic Harapan Bersama, who had provided in the form of funding for this study. We also appreciate to RSUI Harapan Anda for allowing this study to be carried out and for directing to the informants. Appreciation to the informants who have been willing to take the time to provide the information we need.

\section{REFERENCES}

[1] C. Preto, H. Soares, A. Martins, H. Guimarães, J. Spratley, and M. Tavares, "Congenital cytomegalovirus infection in an extremely preterm newborn exposed to chemotherapy in utero," Journal of Pediatric and Neonatal Individualized Medicine (JPNIM), vol. 7, no. 1, pp. 1-6, 2018.

[2] R. Goelz, K. Hamprecht, K. Klingel, and C. F. Poets, "Intestinal manifestations of postnatal and congenital cytomegalovirus infection in term and preterm infants," Journal of Clinical Virology, vol. 83, pp. 29-36, 2016.

[3] A. A. Lopes, V. Champion, and D. Mitanchez, "Nutrition of preterm infants and raw breast milk-acquired cytomegalovirus infection: French national audit of clinical practices and diagnostic approach," Nutrients, vol. 10, no. 8, pp. 1119-1132, 2018. 
[4] I. Maulida, R. S. Prastiwi, and A. M. Chikmah, "Case Study: Signs and Cases of Cytomegalovirus in Toddlers (In Bahasa Indonesia)," Journal Research Midwifery Politeknik Tegal, vol. 8, no. 1, pp. 21-27, 2019.

[5] M. Agholi, A. Safaei, M. Ramzi, G. R. Hatam, and J. Sarvari, "A survey of the frequency of cytomegalovirusassociated diarrhea in immunocompromised patients using a non-invasive method," Iranian Journal of Microbiology, vol. 10, no. 2, pp. 143-150, 2018.

[6] M. K. Ibrahim, M. Zambruni, C. L. Melby, and P. C. Melby, "Impact of Childhood Malnutrition on Host Defense and Infection," Clinical Microbiology Reviews, vol. 30, no. 4, pp. 919-971, 2017.

[7] J. L. Walson and J. A. Berkley, "The impact of malnutrition on childhood infections," Current Opinion in Infectious Diseases, vol. 31, no. 3, pp. 231-236, 2018.

[8] D. K. Kinyoki, J. A. Berkley, G. M. Moloney, N. B. Kandala, and A. M. Noor, "Predictors of the risk of malnutrition among children under the age of 5 years in Somalia," Public Health Nutrition, vol. 18, no. 17, pp. 3125-3133, 2015.

[9] B. R. Bait, J. H. Rah, A. Roshita, R. Amaheka, V. Chrisnadarmani, and M. R. Lino, "Community engagement to manage acute malnutrition: implementation research in Kupang district, Indonesia," Bulletin of the World Health Organisation, vol. 97, no. 9, pp. 597-604, 2019.

[10] Y. Lee, O. Kwon, C. S. Shin, and S. M. Lee, "Use of Bioelectrical Impedance Analysis for the Assessment of Nutritional Status in Critically Ill Patients," Clinical Nutrition Research, vol. 4, no. 1, pp. 32-40, 2015.

[11] T. Huriah, "Influence of Home Visit Against Decreased Infectious Disease Episodes and Increased Nutrition Adequacy Rates in Toddlers of Severe Acute Malnutrition, (In Bahasa Indonesia)," Jurnal Ners dan Kebidanan Indonesia, vol. 5, no. 1, pp. 33-41, 2017.

[12] S. Adelia and J. C. Susanto, "Mid-upper arm circumference measurement for severe malnutrition screening in underfives," Paediatrica Indonesiana, vol. 60, no. 1, pp. 42-52, 2020.

[13] H. C. Stobaugh et al., "Children with Poor Linear Growth Are at Risk for Repeated Relapse to Wasting after Recovery from Moderate Acute Malnutrition," The Journal of Nutrition, vol. 148, no. 6, pp. 974-979, 2018.

[14] B. Murti, "Design and sample size for quantitative and qualitative research in the field of health (In Bahasa Indonesia)," Yogyakarta: Gadjah Mada University Press, 2013.

[15] E. S. Sulaeman, "Qualitative and Mixed Research in Public Health (In Bahasa Indonesia)," Surakarta: UNS PRESS, 2015.

[16] R. S. Prastiwi, U. R. Budihastuti, and M. Wijaya, "Phenomenology Study: Factors Associated with the Choice of Unskilled Traditional Birth Attendants in Brebes, Central Java," Journal of Maternal and Child Health, vol. 1, no. 4, pp. 242-249, 2016.

[17] A. Eka, "Kesehatan Ibu dan Anak (KIA) Dalam Millenium Development Goals (MDG's)", Yogyakarta: Nuha Medika, 2012.

[18] Y. Fekadu, A. Mesfin, D. Haile, and B. J. Stoecker, "Factors associated with nutritional status of infants and young children in Somali Region, Ethiopia: A cross- sectional study Global health,” BMC Public Health, vol. 15, no. 1, pp. 846-855, 2015.

[19] Y. Wang, Z. Huang, Z. Ye, C. Zheng, Z. Jiang, and Y. Huang, "Cytomegalovirus enteritis with intractable diarrhea in infants from a tertiary care center in China," Scandinavian Journal of Gastroenterology, vol. 55, no. 1, pp. 55-61, 2020.

[20] P. K. Sue, N. M. Salazar-Austin, O. G. McDonald, A. Rishi, T. C. Cornish, and R. Arav-Boger, "Cytomegalovirus Enterocolitis in Immunocompetent Young Children: A Report of Two Cases and Review of the Literature," The Pediatric Infectious Disisease Journal, vol. 35, no. 5, pp. 573-576, 2016.

[21] Z. A. Bhutta, J. A. Berkley, R. H. J. Bandsma, M. Kerac, I. Trehan, and A. Briend, "Severe childhood malnutrition," Nature reviews Disease primers, vol. 3, no. 1, p. 17067, 2017.

[22] A. Kumar et al., "Impact of nutrition and rotavirus infection on the infant gut microbiota in a humanized pig model," BMC Gastroenterology, vol. 18, no. 1, pp. 93-110, 2018.

[23] D. J. Millward, "Nutrition, infection and stunting: The roles of deficiencies of individual nutrients and foods, and inflammation, as determinants of reduced linear growth of children," Nutrition Research Reviews, vol. 30, no. 1, pp. 50-72, 2017.

[24] D. Primayani, "Nutritional Status of Acute Diarrhea Patients in the Inpatient Room of SoE Hospital, Timor Tengah Selatan District, NTT (In Bahasa Indonesia)," Sari Pediatri, vol. 11, no. 2, pp. 90-93, 2016.

[25] J. C. Preiser et al., "Metabolic and nutritional support of critically ill patients: Consensus and controversies," Critical Care, vol. 19, no. 1, pp. 35-46, 2015.

[26] L. Denney, M. C. Afeiche, A. L. Eldridge, and S. Villalpando-Carrión, "Food Sources of Energy and Nutrients in Infants, Toddlers, and Young Children from the Mexican National Health and Nutrition Survey 2012," Nutrients, vol. 9, no. 5, pp. 494-521, 2017.

[27] D. K. Olney, L. Bliznashka, A. Pedehombga, A. Dillon, M. T. Ruel, and J. Heckert, "A 2-Year Integrated Agriculture and Nutrition Program Targeted to Mothers of Young Children in Burkina Faso Reduces Underweight among Mothers and Increases Their Empowerment: A Cluster-Randomized Controlled Trial," Journal Nutrition, vol. 146, no. 5, pp. 1109-1117, 2016.

[28] R. E. Blaine, A. Kachurak, K. K. Davison, R. Klabunde, and J. O. Fisher, "Food parenting and child snacking: A systematic review," International Journal of Behavioral Nutrition and Physical Activity, vol. 14, no. 1, pp. 146-169, 2017.

[29] D. J. Corsi, I. Mejía-Guevara, and S. V. Subramanian, "Risk factors for chronic undernutrition among children in India: Estimating relative importance, population attributable risk and fractions," Social Science and Medicine, vol. 157, pp. 165-185, 2016.

[30] S. Scaglioni, V. De Cosmi, V. Ciappolino, F. Parazzini, P. Brambilla, and C. Agostoni, "Factors Influencing Children's Eating Behaviours," Nutrients, vol. 10, no. 6, pp. 706-723, 2018. 
[31] C. M. Kastorini et al., "National Dietary Guidelines of Greece for children and adolescents: A tool for promoting healthy eating habits," Public Health Nutrition, vol. 22, no. 14, pp. 2688-2699, 2019.

[32] S. Higgs and J. Thomas, "Social influences on eating," Current Opinion in Behavioral Sciences, vol. 9, pp. 1-6, 2016.

[33] N. V. Lopez et al., "Parenting styles, food-related parenting practices, and children's healthy eating: A meditation analysis to examine relationships between parenting and child diet," appetite, vol. 128, pp. 205-213, 2018.

[34] N. Sharma, E. L. Ferguson, A. Upadhyay, E. Zehner, S. Filteau, and A. M. Pries, "Perceptions of commercial snack food and beverages for infant and young child feeding: A mixed-methods study among caregivers in Kathmandu Valley, Nepal-Sharma-2019-Maternal \& amp; Child Nutrition-Wiley Online Library,” Maternal and Child Nutrition, vol. 15, no. S4, 2019.

[35] Z. Kazmi, I. Fatima, S. Perveen, and S. S. Malik, "Monosodium glutamate: Review on clinical reports," International Journal of Food Properties, vol. 20, no 5, pp. 1-9, 2017.

[36] C. V. Vorhees, "A Test of Dietary Monosodium Glutamate Developmental Neurotoxicity in Rats: A Reappraisal," Annals of Nutrition and Metabolism, vol. 73, no. Suppl. 5, pp. 36-42, 2018.

Int. J. Public Health Sci, Vol. 9, No. 2, June 2020: 97 - 102 